\title{
UPAYA GURU DALAM MEMBENTUK KARAKTER ANAK ISLAM USIA DINI DI TK AL-KHAIRAAT UEDELE KEC. TOJO KAB. TOJO UNA-UNA
}

\author{
Sulistiawati ${ }^{1)}$ Fatimah Saguni ${ }^{2)}$ Marwany ${ }^{3)}$ \\ ${ }^{1}$ Mahasiswa Program Studi PIAUD FTIK Institut Agama Islam Negeri Palu \\ ${ }^{2}$ Dosen Fakultas Tarbiyah dan Ilmu Keguruan, Institut Agama Islam Negeri Palu \\ ${ }^{3}$ Dosen Fakultas Tarbiyah dan Ilmu Keguruan, Institut Agama Islam Negeri Palu
}

\begin{abstract}
ABSTRAK
Penelitian ini bertujuan untuk mengetahui upaya yang dilakukan oleh guru dalam membentuk karakter anak islam usia dini, serta kendala dan solusi guru dalam membentuk karakter anak Islam usia dini di TK Al-Khairaat Uedele, Kecamatan Tojo, Kabupaten Tojo Una-Una. Metode Penelitian yang digunakan yaitu pendekatan kualitatif deskriptif, dengan teknik pengumpulan data melalui observasi, wawancara, dan dokumentasi. Hasil penelitian ini menunjukan bahwa dalam pelaksanaan, pembentukan karakter pada anak usia dini di Sekolah TK Al-Khairaat Uedele dalam membentuk karakter tersebut dilakukan dengan berbagai upaya yaitu melalui bernyanyi, bermain, pembiasaan anak mencium tangan pada guru, membiasakan menjawab salam dan bertanggung jawab. menerapkan perilaku disiplin. Adapun kendala serta solusi yang dihadapi oleh lembaga pendidikan formal dalam membentuk karakter pada anak usia dini di sekolah TK Al-Khairaat Uedele adalah dengan beragamnya sikap anak, guru belum terlalu menguasai lagu, aturan yang diterapkan belum sepenuhnya dipatuhi oleh peserta didik serta terbatasnya sarana dan prasarana. kemudian solusi untuk pemerintah yaitu menambah atau memperbaiki fasilitas yang ada di sekolah TK Al-Khairaat Uedele, Guru selalu mengingatkan kepada peserta didik tentang tata tertib kelas serta melakukan tanya jawab dengan peserta didik pada saat selesai berbaris dan masuk kelas. Dari kesimpulan yang diperoleh bahwa diharapkan kepada pendidik terutama guru yang ada di TK Al-Khairaat Uedele agar lebih memperhatikan lagi pendidikan nilai karakter pada peserta didik terutama pada Anak Usia Dini.
\end{abstract}

Kata Kunci : Karakter, Anak usia dini

\section{PENDAHULUAN}

Pendidikan tidak hanya proses mentransfer ilmu dari guru untuk murid, tetapi juga harus diiringi dengan upaya memberikan keteladanan dari pendidik dalam pembentukan karakter anak didik. Oleh karena itu, seorang guru harus berupaya dalam membentuk karakter anak didiknya, agar dapat melahirkan anak didik yang berilmu, berkarakter, beradab, dan berakhlak mulia. Karena, berilmu, berakhlak, berkarakter dan beradab adalah bagian dari pendidikan Rasulullahshallallahualaihi wasalam. ${ }^{1}$ Model pendidikan yang di ajarkan Rasulullah bukan hanya pendidikan yang membentuk akal yang cerdas,

\footnotetext{
${ }^{1}$ Ulil Amri Syafri, Pendidikan Karakter Berbasis Al-Qur'an, (Cet, ke-02, Jakarta : PT Rajawali Pers, 2014), 41.
} 
tetapi juga membentuk kepribadian yang dapat mengasah kepekaan jiwa agar dapat menjadi pribadi yang bermanfaat bagi sekitarnya. Maksudnya dapat menjadi pribadi yang peka dengan persoalanpersoalan yang ada disekitar kita.

Jadi, sebagai seorang guru harus sadar bahwa mereka itu tidak hanya mengajar tetapi mereka juga harus bisa mendidik anak didiknya dengan baik. Karena, sekarang ini banyak terjadi bahwa seorang guru kurang perduli dengan akhlak, adab, sikap dan perilaku anak didiknya, yang mereka fikirkan hanyalah mengajar mereka tidak sadar bahwa mendidik juga menjadi tanggung jawab mereka. Kenapa orang tua menyekolahkan anaknya karena, mereka sadar bahwa ilmu mereka itu masih kurang untuk membentuk karakter anaknya.

Dalam bahasa Indonesia "karakter" diartikan sebagai tabiat, sifat-sifat kejiwaan, akhlak atau budi pekerti yang membedakan seseorang dengan yang lain. ${ }^{2}$ Secara umum, pendidikan karakter sesungguhnya dibutuhkan semenjak anak berusia dini. Apabilah karakter seseorang sudah terbentuk sejak usia dini, ketika dewasa tidak akan mudah berubah meskipun godaan atau rayuan datang begitu menggiyurkan. Untuk memahami istilah karakter tersebut, menurut kamus besar bahasa indonesia, karakter adalah sifatsifat kejiwaan, akhlak, atau budi pekerti yang membedakan seseorang dari yang lain. ${ }^{3}$

Permasalahan karakter pada anak maupun remaja pada saat ini sangat memprihatinkan. Karena sekarang ini tidak hanya sedikit anak dan remaja yang memiliki sikap dan perilaku yang kurang baik. Hal ini dapat mempengaruhi masa depan mereka dan akan melahirkan anak bangsa yang kurang berkarakter, maka sebagai orang dewasa sudah menjadi tugas atau kewajiban untuk membimbing dan membentuk karakter anak sejak dini. Karena bila kita sebagai orang dewasa membiarkan hal tersebut akan semakin meningkat jika tidak ditangani secara serius oleh pihak-pihak terkait. Anak dan remaja merupakan generasi penerus bangsa, di masa ini perilaku dan sikap yang dimiliki mereka masih labil tergantung pengaruh lingkungan yang di dapatkan. Apabila pengaruh yang di dapatkan itu merupakan pengaruh negative maka hal ini akan dapat membahayakan masa depan mereka. Pengaruh negative itu dapat dengan mudah mereka dapatkan melalui lingkungan keluarga, masyarakat dan sekolah atau dari faktor eksternal maupun faktor internal. Lingkungan keluarga juga mempunyai pengaruh besar dalam mendidik anak maupun remaja yang sedang ingin mencari jati dirinya itu. Menghadapi permasalahan yang ditimbulkan dari faktor internal maupun eksternal anak yang takkunjung menemukan titik terang, maka diperlukan kerjasama dari berbagai pihak.

Lembaga pendidikan dan sosok guru serta para orang tua banyak berharap agar anak-anak mereka dapat menimbah ilmu ditempat tersebut dan dapat menjadi anak yang berkarakter kemudian dapat mengembangkan potensi yang dimilikinya. TK Al-Khairaat Uedele adalah salah satu lembaga pendidikan yang berada di Kecamatan Tojo, kemudian

\footnotetext{
${ }^{2}$ Suyadi, Strategi Pembelajaran Pendidikan Karakter, (Bandung: Pt Remaja Rosdakarya,2013), 5.

${ }^{3}$ Akhmad muhaimin azzet, urgensi pendidikan karakter di indonesia, (cet, 2, jogjakarta: ar-ruzz media, 2013), 16.
} 
lembaga pendidikan ini, ikut andil dalam melaksanakan pendidikan untuk penciptakan generasi yang berkualitas, berakhlak baik, cerdas dan mandiri. TK Al-Khairaat Uedele juga menerapkan pendidikan karakter kepada anak didik mereka seperti; tata cara makan yang baik, minum, mengeluarkan bahasa yang baik atau berbicara dengan teman dan orang yang lebih tua, tata cara belajar, dan sebagainya. Hal inilah yang membuat penulis tertarik untuk meneliti tentang pendidikan karakter anak usia dini di TK Alkhairaat Uedele yaitu upaya guru dalam membentuk karakter anak usia dini. Penelitian ini bertujuan untuk mengetahui upaya guru dalam membentuk karakter Anak Islam Usia Dini serta kendala yang dialami oleh guru dalam membentuk karakter Anak Islam Usia Dini di TK Al-Khairaat Uedele, Kec. Tojo, Kab. Tojo Una-Una

\section{METODE PENELITIAN}

Pendekatan penelitian yang digunakan adalah pendekatan kualitatif karena focus penelitian ini bersifat mendeskripsikan tentang pembentukan karakter pada anak usia dini. Dalam penelitian ini, penulis mengambil tempat di sekolah TK Alkhairaat Uedele. Kehadiran peneliti merupakan hal yang penting di lokasi penelitian, mengingat jenis penelitian yang digunakan adalah penelitian kualitatif dan dalam penelitian ini peneliti bertindak sebagai instrumen sekaligus pengumpul data.

Dalam penelitian ini, terdapat jenis data yang dikumpulkan yaitu data primer dan data sekunder. Data primer diperoleh atau dikumpulkan langsung dari lapangan melalui pengamatan langsung dan wawancara. Sedangkan data sekunder yang dimaksud adalah data yang diperoleh melalui dokumentasi, dan catatan yang berkaitan dengan objek penelitian.

Teknik pengumpulan data yang digunakan dalam pelaksanaan penelitian ini meliputi teknik observasi, dokumentasi dan wawancara. Adapun teknik analisis data terdiri dari reduksi data, penyajian data dan verifikasi data. Pengecekan keabsahan data dalam penelitian ini dilakukan penulis melalui diskusi dengan berbagai kalangan yang memahami masalah penelitian ini.

\section{HASIL DAN PEMBAHASAN}

\section{A. Upaya Guru Dalam Membentuk Karaktek Anak Islam Usia Dini di TK Alkhairaat Uedele}

Upaya yang dilakukan oleh guru dalam membentuk karakter peserta didiknya di TK Al-Khairaat Uedele Kec. Tojo Kab. Tojo Una-Una maka, penulis melakukan penelitian dengan menggunakan tekhnik observasi atau pengamatan dan wawancara secara terbuka dan mendalam kepada sumber data atau sumber informasi. Yang berkaitan dengan upaya guru dalam membentuk karakter peserta didiknya dengan melakukan wawancara pada kepala Sekolah Taman Kanak- Kanak Al-Khairaat Uedele dengan hasil wawancara sebagai berikut:

Saya selaku guru dan sekaligus kepala sekolah di sini dalam membentuk karakter peserta didik dengan cara melakukan perencanaan kegiatan dalam pembelajaran yang akan dilakukan dengan melalui tema tertentu, dan 
kemudian merencanakan karakter apa yang akan dibentuk dalam tema tersebut yang dapat dijadikan sebagai kebiasaan dalam berperilaku seharihari seperti tema keluarga sakina maka karakter yang akan ditanamkan adalah bagaimana cara berjalan kalau didepannya orang tua, cara berbicara kepada orang tua dan lainnya. ${ }^{4}$

Secara umum, pendidikan karakter sesungguhnya dibutuhkan semenjak anak berusia dini. Apabilah karakter seseorang sudah terbentuk sejak usia dini, ketika dewasa tidak akan mudah berubah meskipun godaan atau rayuan datang begitu menggiurkan. Untuk memahami istilah karakter tersebut, menurut kamus besar bahasa Indonesia, karakter adalah sifat-sifat kejiwaan, akhlak, atau budi pekerti yang membedakan seseorang dari yang lain. ${ }^{5}$

Dapat dipahami bahwa dalam melakukan pembentukan karakter pada Anak Usia Dini itu sangat penting dan dapat dilakukan dengan usaha melalui pembiasaan dalam berperilaku sehari-hari yang akan ditanamkan kepada peserta didik dengan tema tertentu dalam hal ini, seperti yang disebutkan diatas bahwa pendidikan karakter sesungguhnya sangat dibutuhkan sejak usia dini karena, anak yang sudah terbentuk karakternya sejak dini maka, apabila dewasa nantinya tidak akan mudah berubah dengan mengingat bahwa karakter tersebut adalah sesuatu yang berkaitan dengan jiwa, akhlak, budi pekerti dan kemudian yang dapat membedakan seseorang dengan yang lain.

Setelah melakukan perencanaan kemudian kami melakukan pelaksanaan, pelaksanaan yang dimaksud disini yaitu pelaksanaan tema yang telah kami rencanakan untuk membentuk karakter anak didik kami. ${ }^{6}$

Jadi, yang dimaksud dari hasil wawancara diatas dapat dipahami bahwa setelah melakukan perencanaan kemudian melakukan pelaksanaan. Pelaksanaan yang dimaksud, bagaimana seorang guru melaksanaan pembelajaran yang sudah direncanakan lalu diterapkan atau diajarkan kepada peserta didik misalnya, guru merencanakan tema keluarga dalam pembelajaran kemudian tema tersebut akan dilaksanakan dengan cara menjelaskan kepada peserta didik tentang keluarga (anggota keluarga, cara berbicara dengan kedua orang tua, dll).

Kemudian dilanjutkan dengan penilaian kepada peserta didik dengan cara melihat, mengamati, mengawasi peserta didik apabilah ada yang melanggar peraturan dengan sengaja maupun tidak sengaja karena, peserta didik terutama yang masih usia dini akan melakukan sesuatu yang melanggar peraturan apabila melihat ada cela untuk melakukan pelanggaran maka, dari itulah peserta didik membutuhkan pengawasan dari guru maupun

\footnotetext{
${ }^{4}$ Nurhani, kepala Sekolah Taman Kanak-Kanak Al-Khairat Uedele, "wawancara," disekolah pada tanggal, 21. Juli 2018.

5 Akhmad muhaimin azzet, urgensi pendidikan karakter di indonesia, 16.Juli 2018

${ }^{6}$ Nurhani, kepala sekolah, “wawancara,” disekolah pada tanggal, 21.Juli 2018.
} 
orang dewasa yang berada disekitarnya. Hal ini sama seperti yang disebutkan oleh informan sebagai berikut:

Setelah itu melakukan penilaian atau evaluasi. Jadi, evaluasinya yaitu dengan cara pengawasi mereka menjaga-jaga apabila ada yang melanggar peraturan yang telah ditentukan kemudian apabilah kami menemukan hal. Tersebut maka kami akan memberitahukan atau mengingatkan kembali tentang peraturan yang ada disekolah ini karena dengan begitu mereka akan terbiasa mentaati peraturan dan dapat mengembangkan karakter bertanggung jawab. ${ }^{7}$

Pembentukan karakter anak pada usia dini di TK Al-Khairaat Uedele diterapkan agar peserta didik dapat tertanamkan pada diri mereka tentang nilai- nilai karakter atau perilaku yang baik pada diri peserta didik sejak mereka masih usia dini agar peserta didik mampu membawa diri mereka sampai jenjang selanjutnya dan mampu menanamkan dalam jiwa mereka nilai karakter tersebut hingga peserta didik masuk usia dewasa, Hal ini sejalan dengan pernyataan informan berikut ini:

Karakter merupakan nilai-nilai perilaku manusia yang berhubungan dengan Tuhan Yang Maha Esa, diri sendiri, sesama manusia, lingkungan, dan kebangsaan yang terwujud dalam pikiran, sikap, perasaan, perkataan, dan perbuatan berdasarkan norma-norma agama, hukum, tata krama, budaya, dan adat istiadat.yang harus di terapkan kepada anak sejak mereka masih di usia dini melalui proses belajar mengajar. ${ }^{8}$

Hal ini di terapkan agar anak mampu berinteraksi serta berkalaborasi dengan lingkungannya kelak. Karena, Pendidikan karakter yaitu merupakan suatu sistem penanaman nilai-nilai karakter kepada anak usia dini di Desa Uedele agar mampu mengembangkan diri mereka ke hal-hal yang positif ketika anak dewasa nanti dan juga hal tersebut akan menentukan karakter peserta didik nantinya, apakah mereka memiliki perilaku baik atau tidaknya. Semua itu tergantung dari pembentukan karakter yang didapatkan sejak dini.

Seorang guru tidak hanya mengajarkan peserta didiknya tentang cara menulis, membaca, dan berhitung. Tetapi guru juga harus membimbing dan membentuk karakter peserta didiknya agar menjadi anak bangsa yang berkarakter, seorang guru bisa dikatakan sebagai orang tua pengganti bagi peserta didiknya. Mengapa perlu membentuk karakter peserta didik karena, masing-masing peserta didik memiliki karakter yang berbeda-beda tergantung bagaimana keluarganya mendidik mereka dari sejak lahir. Secara alami karakter yang dimiliki peserta didik bisa berasal dari gen orang tuanya kemudian cara orang tuanya mendidik mereka dirumah sehingga terbentuklah karakter yang baik dan karakter yang tidak baik. Maka dari itulah sosok seorang guru dan campur tangan seorang

\footnotetext{
${ }^{7}$ Nurhani, kepala sekolah, “wawancara," disekolah pada tanggal, 21.Juli 2018.

${ }^{8}$ Nurhayati, Guru, "wawancara" di Rumah beliau pada tanggal, 22 Juli 2018
} 
guru sangatlah dibutuhkan mengingat terbatasnya pengetahuan orang tua mengenai pembentukan karakter pada anak kemudian peserta didik lebih mendengarkan apa yang diperintahkan gurunya dibandingkan perintah orang tua mereka sendiri. Hal ini sesuai dengan hasil wawancara yang dilakukan dengan informan sebagai berikut:

Dalam mengajar Anak-anak apalagi anak usia dini sebagai seorang guru tidak hanya mencerdaskan tetapi juga harus bisa membimbing mereka untuk memiliki perilaku atau sikap yang baik karena, itu semua akan menentukan masa depan mereka nantinya. Terutama watak mereka, sebagai guruharus berusaha lebih keras lagi dalam membentuk karakter anak didik kami, mungkin karena mereka dibesarkan dan dididik dari keluarga atau orang tua yang berbeda-beda guru disinijuga dapat disebut sebagai orang tua kedua bagi anak didiknya. ${ }^{9}$

Dapat dipahami bahwa mengapa seorang guru memiliki kewajiban yang lain selain mencerdakan peserta didiknya karena, salah satu fungsi guru tidak hanya mencerdaskan tetapi juga harus bisa membimbing peserta didiknya agar peserta didiknya dapat terarahkan dalam melakukan sesuatu sehingga peserta didik tidak salah dalam melakukan hal tersebut.

Dalam melaksanakan usaha untuk membentuk karakter peserta didik maka, dapat dilakukan dengan cara- cara yang merupakan suatu pembiasaan yang akan diterapkan kepada peserta didik agar dapat menjadi kebiasaan mereka, dalam sehari-hari dengan harapan agar terbentuk perilaku yang baik pada diri peserta didik agar dapat menjadi anak bangsa yang berperilaku yang baik bagi Bangsa dan Negaranya. Adapun cara-cara tersebut sebagai berikut:

\section{Membiasakan Anak Untuk Cium Tangan Kepada Guru}

Dalam proses belajar mengajarkan perlu menerapkan karakter hormat dan santun sejak usia dini karena, karakter ini sangat penting pada saat peserta didik beranjak dewasa. Dengan belajar menghormati orang, maka anak akan dihargai oleh orang lain kalimat inilah yang ditanamkan dalam diri peserta didik. Cara menghormati orang yang dilakukan peserta didik adalah dengan cara bersalaman dan mencium tangan ibu guru dan mengucapkan salam. Bukan hanya itu saja peserta didik juga diajarkan atau diberitahukan bahwa kalau lewat didepan orang lain atau orang tua peserta didik harus membungkukan badan sambil mengucapkan tabe, kemudian apabila orang tua sedang berbicara dengan tamu peserta didik tidak boleh mengganggu. Hal ini disebutkan oleh informan berikut ini:

Kami juga membiasakan cara bersikap hormat dan santun kepada muridmurid disini. Jadi, cara kami mengajarkan kepada mereka yaitu membiasakan mereka bersalaman dengan mencium tangan ibu guru dan mengucapkan salam, kemudian kami juga menjelaskan pada mereka apabila sampai

\footnotetext{
${ }^{9}$ Sawiah, Guru dan bendahara Sekola TK Al-Khairaat, "wawancara,"di Rumah beliau pada tanggal, 22 Juli 2018.
} 
dirumah harus mengucapkan salam, lalu bersalaman dan mencium tangan orang tua atau orang-orang yang lebih tua dari mereka yang ada didalam rumanya, tidak boleh mengganggu orang tua yang sedang berceritakalau lewat didepan orang tua harus membungkukkan badan lalu mengucapkan tabe. ${ }^{10}$

Nilai dasar yang menjadi landasan dalam membangun karakter adalah hormat (respect). Hormat tersebut mencangkup respek pada diri sendiri, orang lain, semua bentuk kehidupan maupun lingkungan yang mempertahankannya. Dengan memiliki hormat, maka individu memandang dirinya maupun orang lain menjadi sesuatu yang berharga dan memiliki hak yang sederajat.

Dapat dipahami bahwa di Sekolah TK Al-Khairaat Uedele membiasakan peserta didiknya untuk bersikap hormat dan santun dengan cara mengajarkan kepada peserta didiknya bersalaman atau mencium tangan orang dewasa hal ini dilakukan karena, guru yang ada di Sekolah TK tersebut percaya bahwa dengan menerapkan pembiasaan bersalaman dan mengucapkan kata tabe itu, dapat membentuk sikap hormat dan santun hal tersebut dikarenakan budaya di dalam lingkungan masyarakat yang sudah dilakukan secara turun-temurun, masyarakat meyakini bahwa apabila ada anak atau seseorang yang lewat didepan orang tua tidak mengucapakan tabe dan tidak bersalaman maka mereka akan mengatakan bahwa sikap seseorang tersebut tidak baik dan kemudian rasa hormat adalah nilai dasar yang menjadi landasan dalam membangun karakter.

Hal tersebut rutin dilakukan terutama pada pagi hari saat penyambutan kedatangan anak ketika di sekolah tersebut. Tradisi cium tangan kepada guru ketika menyambut kedatangan anak pada saat ini juga sudah dilakukan oleh kebanyakan dari lembaga pendidikan baik yang berbasis Islam atau tidak. Hal ini karena cium tangan sudah menjadi tradisi dari masyarakat pada umumnya sebagai bentuk untuk menghormati anak kepada orang tua, guru maupun orang lain agar anak pada usia ini mampu menerapkan hal tersebut dari sekarang hingga mereka dewasa kelak.

Sebagaimana hasil wawancara penulis bersama beliau Ibu Lina Rambalino sebagai berikut:

Hal ini diterapkan karena pada masa sekarang ini rasa semangat hormat menghormati anak dengan guru maupun orang tua semakin terkikis, golongan mudah sudah mulai berkurang rasa hormat mereka kepada yang lebih tua, baik dari segi tutur bahasa maupun kelakuan. Hal ini mungkin disebabkan karena budaya serta perkembangan zaman pada era sekarang ini. Maka dari itu sebagai pendidik dalam hal ini guru harus menanamkan hal tersebut kepada anak sejak usia dini agar anak mampu mencontohi hal tersebut sampai anak dewasa dan keluar dari lingkungannya. ${ }^{11}$

\footnotetext{
10 Lina Rambalino, Guru Sekolah Tk Al-Khairaat Uedele, "wawancara," di Rumah beliau pada tanggal, 28 Juli 2018.

11 Lina Rambalino, Guru, “Wawancara” di rumah beliau pada tanggal, 28 Juli 2018.
} 
Karakter yang berupa sikap menghormati guru dan orang tua dan sikap menyayangi, menghargai serta menghormati sengaja ditanamkan guru kedalam pribadi anak ketika mereka masih usia dini agar anak mampu menanamkan nilai karakter tersebut hingga terbawa pada usia dewasa menjadikan kondisi yang harmonis seimbang mengenal kewajiban mereka menghormati yang lebih tua. dan hal ini merupakan salah satu tugas guru TK Al-Khairaat Uedele dalam mengenalkan serta menanamknan nilai-nilai yang positif kepada anak untuk membentuk mental serta pribadi anak itu sendiri dari sekarang.

Selain Upaya yang di lakukan dalam pembentukan karakter di atas, yang diharapkan ada dalam diri anak usia dini yaitu karakter Islami.

\section{Membiasakan Sikap Menjawab Salam dan Antrian Kepada Anak Usia Dini}

Karakter lain yang diharapkan ada dalam diri anak usia dini pada TK Al-Khairaat Uedele adalah terbiasa untuk mengucapkan salam serta budaya antrian ketika bertemu guru, orang tua maupun teman yang lain dan membiasakan budaya antri agar anak lebih mengetahui arti saling menghargai, menghormati serta sopan santun ketika dalam proses pembelajaran maupun dilingkungan lainnya. Sebagaimana pendapat informan sebagai berikut:

Membiasakan mengucapkan salam serta budaya antrian kepada anak sejak mereka usia dini akan membawa dampak yang baik bagi pertumbuhan anak. pada masa usia ini akan lebih baik untuk membiasakan merekamengucapkan salam serta antrian. Dengan adanya budaya salam serta antrian tersebut maka akan timbul sebuah rasa kasih sayang di antara sesama manusia dan menghilangkan rasa kebencian, menanamkan sikap kesabaran, serta ke ikhlasan agar anak mampu mengimplementasikan dalam kehidupan mereka sebagai yang lebih mudah untuk menghormati yang lebih tua dari mereka yaitu guru serta orang tua. ${ }^{12}$

Dapat dipahami bahwa dengan membiasakan anak untuk menjawab salam dan antri akan berdampak baik bagi pertumbuhannya, karena pada masa ini anak disebut masa keemasan yang mana mereka memiliki rasa ingin tahu yang tinggi, suka meniru dan sebagainya. Maka dari itulah menerapkan pembiasaan pada anak sejak dini akan lebih baik dalam proses pembelajaran, ada yang namanya evaluasi dalam evaluasi ini peserta didik ditanya satu persatu mengenai hasil karya yang dibuat oleh peserta didik pada saat yang sama, kebanyakan peserta didik meminta untuk diutamakan atau dinomor satukan dari teman-temannya yang lain, begitu pun yang lain. Maka disinilah peran guru sangat diperlukan untuk membentuk karakter disiplin dan antri. Seperti yang diungkapkan oleh informan berikut ini:

Murid-murid disini sering kami ajarkan untuk disiplin seperti kalau mengantar hasil karya mereka. Jadi, pada saat mengatarkan hasil karya mereka kedepan biasanya berebutan tidak mau bergantian atau satupersatu maka kami sebagai guru memberikan motivasi dengan cara mengucapkan

12 Nurhayati, Guru, wawancara, di ruangan beliau pada tanggal, 30 Juli 2018. 
kalimat "anak baik mau bergantian", "tunggu ya, sampai dipanggil ibu guru", "ayo, buat barisan yang rapi, kita budayakan antri”. Dan banyak kalimat lainnya untuk memotivasi anak-anak didik disini kemudian setelah proses pembelajaran selesai kami sebagai guru harus menjelaskan kembali kepada mereka bahwa yang mereka lakukan "sambil menyebutkan nama mereka satu-persatu" tadi itu adalah hal yang baik dan harus dilakukan setiap hari atau seterusnya. ${ }^{13}$

Dapat dipahami bahwa ternyata dalam mengajar anak-anak kata perintah dan larangan hanya bagian terkecil dalam usaha membentuk karakter.karena, pada dasarnya Anak Usia Dini tersebut apabila mereka diperintah dan dilarang untuk melakukan suatu hal sebagai guru juga harus menjelaskan kepada mereka mengenai alasan mereka memerintahkan dan melarang hal tersebut untuk dilakukan. Jadi, sebagai guru harus memiliki berbagai cara untuk menjelaskan kepada mereka kemudian yang dapat memotivasi juga.

TK Al-Khairaat Uedele merupakan salah satu TK yang membuat tata tertib atau peraturan untuk mendisiplikan anak-anak pada usia dini ini di TK AlKhairaat Uedele, bertujuan agar peserta didik dapat menjadi insan atau manusia yang memiliki karakter baik. Yayasan TK Al-Khairaat ini memiliki peraturan yang sangat baik untuk menunjang pendidikan anak bangsa pada usia dini ini yang berkarakter baik sesuai dengan ajaran Islam yang diterapkan oleh guru apabila anak kedapatan melanggar hal tersebut baik berkelahi, terkadang tidak mau mendegarkan nasihat guru dan sebagainya maka diberikan sangsi hal ini dilakukan untuk melatih diri peserta didik pada usia ini.

\section{Membiasakan dengan Bernyanyi}

Membentuk karakter anak usia dini ada beberapa cara yang sering dilakukan, sebagai guru taman kanak-kanak tentunya tidak lepas dari yang namanya bernyanyi dan bermain. Jadi dalam pembelajaran atau pada saat proses pembelajaran berlangsung biasanya dimulai dengan pembacaan do'a kemudian diteruskan dengan kegiatan bernyanyi untuk memberi semangat atau motivasi belajar dan bertujuan agar anak mampu bersosialisasi dengan teman-teman yang lain. Sesudah bernyanyi bersama guru memberikan semangat kepada peserta didiknya untuk naik kedepan dan bernyanyi. Hal ini sama seperti yang disebutkan oleh informan sebagai berikut:

Guru disini jugamelakukan beberapa cara untuk membentuk karakter peserta didik seperti karakter percaya diri dan mandiri. Jadi, untuk menimbulkan rasa percaya diri pada peserta didik kami di sini melakukan dengan cara bernyanyi pada saat peserta didik bernyanyi bersama setelah itu kami menunjuk mereka untuk naik kedepan dan bernyanyi atau beryanyi satu persatu kemudian selesai bernyanyi kami memberikan hadiah berupa acungan jempol atau tepuk tangan. ${ }^{14}$

13 Suriani, Guru, wawancara, diRumah beliau pada tanggal, 29 Juli 2018.

14 Nurhayati, Guru, "wawancara," diRumah beliau pada tanggal, 30 Juli 2018. 
Pembentukan karakter merupakan pendidikan nilai dan dalam pendidikan nilai ada sembilan hal yang tercangkup didalamnya dan saling berkaitan satu sama lain, salah satunya adalah keberanian. "Keberanian yaitu tetap teguh memegang kebenaran, tidak peduli pada tekanan negatif, tidak takut gagal, tidak takut menyuarahkan suara hati, dan berani berbuat karena, merasa benar" ${ }^{\prime 15}$, menanamkan keberanian pada diri peserta didik sejak usia dini akan dapat berdampak baik bagi diri peserta didik karena, dapat meningkatkan rasa percaya diri peserta didik dan juga dapat melatih mental peserta didik.

Pada saat bernyanyi biasanya peserta didik ada yang tidak mau mengeluarkan suaranya kemudian apabilah diberikan kesempatan maju kedepan untuk bernyanyi peserta didik menolak maka disinilah motivasi atau dukungan dari seorang guru dibutuhkan. Karena, dengan memberikan motivasi kepada peserta didik dapat mengembangkan rasa percaya dirinya. Seperti yang diungkapkan oleh salah informan atau guru di sekolah taman kanak-kanak sebagai berikut:

Pada saat mereka disuruh untuk bernyanyi bersama biasanya hanya beberapa orang saja yang kedengaran suaranya yang lainnya diam, jadi kami harus menghampiri mereka yang tidak mau bersuara atau mengeluarkan suaranya dan memberikan semangat "ayo nak, besarkan lagi suaranya seperti temantemanmu yang lain" kemudian pada saat ditanya "siapa yang mau menyanyikan lagu tanganku ada dua?", mereka semua angkat tangan "saya, saya" tetapi giliran ditunjuk misalnya "iya fadilah" silahkan maju di depan tiba-tiba tidak mau karena malu dengan temannya nanti diketawakan temannya. Maka disinilah kami sebagai guru memberikan motivasi dengan kalimat "ayo fadilah, ayo. Fadilah pasti bisa!", dengan memberikan motivasi tersebut mereka akan merasa bahwa mereka bisa bernyanyi sendiri di depan dengan ini, maka tumbuhlah rasa percaya dirinya. ${ }^{16}$

Dalam hal ini untuk membentuk karakter pada peserta didik guru berusaha melakukan penanaman nilai karakter tersebut agarpeserta didik pada usia dini ini mampu menerapkan karakter yang mandiri serta percaya diri hal tersebut tercapai dengan cara melatih anak melalui bernyanyi hal ini dilakukan apabila anak melakukan kesalahan serta melatih mental anak agar berani maju di depan.

Dengan bernyanyi merupakan hal yang penting diterapkan kepada peserta didik pada usia dini karena, bagi anak usia dini bernyanyi merupakan suatu hal yang menyenangkan jadi, sebagai seorang guru harus memiliki banyak cara dalam bernyanyi agar peserta didik dapat menjadi seorang yang berkarakter mandiri dan percaya diri.

\section{Mengajarkan Tentang Tata Cara Shalat Dan Hukumnya}

TK Al-Khairaat Uedele tata cara shalat ini diterapkan oleh guru agar anak usia dini mampu bertanggung jawab kepada diri mereka sejak mereka masih usia dini kepada mereka arti tanggung jawab serta kewajiban kepada sang pencipta, manusia dengan mahluknya serta manusia dengan manusia itu sendiri. Melalui gambar untuk diajarkan

15 Muchlas Samani dan Hariyanto, pendidikan karakter, 119.

16 Nurhayati, Guru, “wawancara," di Rumah beliau pada tanggal, 30 Juli 2018 
kepada anak pada usia ini serta menjelaskan hukum dari shalat tersebut. Salah satu pembentukan karakter disiplin dan bertanggung jawab dengan cara ini merupakan tindakan yang baik untuk masa depan anak-anak didik di TK Al-Khairaat Uedele agar selamat dunia dan akhirat. Sebagaimana yang diungkapkan oleh informan sebagai berikut:

Di sekolah ini juga mengajarkan anak-anak tentang tata cara sholat dan juga bacaannya dengan melalui gambar, sebenarnya kami disini akan mengajarkan mereka dengan melalui praktek langsung. Tetapi tempat untuk melaksanakan paktek belum bisa dikatakan layak karena, tempatnya kecil dan tidak bisa menampung beberapa siswa yang ada di sekolah ini. ${ }^{17}$

Mengajarkan anak usia dini tentang tata cara sholat tentunya sangat penting karena itu, merupakan karakter islamiJadi, sholat merupakan tabiatnya orang muslim dan juga kewajibannya yang dapat membedakan seseorang dengan yang lainnya, kemudian mengajarkan anak usia dini tentang tata cara sholat itu, merupakan hal yang sangat baik untuk ditanamkan pada diri peserta didik agar peserta didik dapat mengenal ajaran agamanya.

Dalam mengenalkan sekaligus mengajarkan tentang tata cara sholat yang baik serta bacaan sholat walaupun, hanya dengan memperlihatkan gambar tata cara sholat yang baik kemudian dijelaskan kembali kepada peserta didik bagaimana sholat dan bacaannya dengan harapan bahwa dapat menjadikan peserta didik sebagai anak bangsa yang memiliki perilaku anak shaleh. Sebagaimana yang diungkapkan oleh informan sebagai berikut:

Dalam mengajari anak tentang tata cara sholat dan do'a selaku guru sholat dengan menunjukan gambar-gambar tata cara sholat berharap supaya anakanak mengetahui cara sholat dan do'a-do'anya sejak dini. karena, itu masuk dalam perilaku anak shaleh. ${ }^{18}$

\section{Dengan Bermain}

Bermain adalah salah satu alternatif yang sangat menyenangkan apabila diterapkan kepada anak-anak pada usia ini salah satu permainan tersebut yaitu menyusun balok, guru membiarkan anak menyusun balok yang berhamburan sesuai dengan kemauan mereka, untuk melatih konsentrasi, serta melatih kesabaran anak menyusun balok tersebut, hal ini di lakukan agar anak mampu menjaga kedisiplinan, serta tanggung jawab.

Dalam melakukan tahapan-tahapan pembiasaan tersebut di atas akan membentuk sikap anak yang mampu disiplin serta mampu bertanggung jawab atas apa yang telah di berikan kepada mereka maka peserta didik di TK Al-Khairaat Uedele akan menjadi

17 Nurhani, kepala Sekolah, “wawancara," di Rumah beliau pada tanggal, 1 Agustus 2018

18 Nurhani, kepala Sekolah, “wawancara," di Rumah beliau pada tanggal, 1 Agustus 2018 
peserta didik yang amanah apabila diberikan tanggung jawab dan juga dapat menerapkannya dalam kehidupan sehari-harinya.

Dalam membentuk karakter anak usia dini tidaklah mudah atau tidak semudah kita membalikan telapak tangan tetapi sebagai seorang guru harus bisa membentuk karakter peserta didiknya karena sudah menjadi salah satu kewajiban mereka. Hal ini sebagai mana hasil wawancara penulis dengan Ibu Sawiah selaku bendahara guru TK Al-Khairaat Desa Uedele yakni:

Sebagian anak-anak pada usia dini ini di Desa Uedele sudah mengerti dan dapat mempertanggung jawabkan amanah yang diberikan guru serta melatih kedisipilinan terhadap anak tersebut. ${ }^{19}$

Jadi, dalam mengajarkan dan membiasakan peserta didik untuk bertanggung jawab sangatlah penting karena, akan melatih peserta didik untuk amanah dan juga dapat tertanamkan jiwa amanah pada diri peserta didik.

\section{B. Kendala dan Solusi Yang Dihadapi Oleh Guru Dalam Membentuk Karakter Anak Islam Usia Dini Di Tk Al-Khairat Uedele Kec. Tojo Kab. Tojo Una-Una.}

Dalam upaya membentuk karakter anak usia dini di Sekolah TK Al-Khairaat Uedele tidaklah mudah seperti apa yang dibayangkan atau tidak semudah membalikan telapak tangan karena, masih banyaknya hambatan-hambatan yang akan kita hadapi, dari hasil penelitian di Sekolah TK Al-Khairaat Uedele dalam membentuk karakter anak usia dini maka dapat dikemukakan bahwa mengenai kendala-kendala yang dihadapi oleh guru dalam melaksanakan pembentukan karakter pada anak didiknya

\section{Guru Belum Terlalu Menguasai Lagu}

Guru yang mengajar di Taman Kanak-Kanak Al-Khairaat Uedele masih ada beberapa guru yang belum menguasai lagu-lagu yang akan dinyanyikan dengan peserta didik karena, dengan alasan bahwa mereka sebenarnya guru SD kemudian dipindahkan ke Sekolah Taman Kanak-Kanak. Seperti yang diungkapkan oleh informan sebagai berikut:

Saya mengajar disini sebenarnya baru berjalan 8 bulan jadi masih banyak belajar dan menyesuaikan dengan anak didik disini terutama saya harus memperbanyak menghafal lagu anak-anak dan do'a sehari-hari. ${ }^{20}$

\section{Sikap Anak yang Beragam}

Taman Kanak-Kanak Al-Khairaat Uedele merupakan sekolah yang memiliki siswa dengan jumlah 15 orang yang berasal dari latar belakang keluarga berbeda-beda pula. Menurut kepala sekolah TKAl-Khairaat Uedele yang sangat menghambat dari pembentukan karakter pada anak yaitu mencegah kebiasaan mereka yang sangat susah untuk diatur. ${ }^{21}$ Menyangkut, kebiasaan mereka yang sangat susah diatur terutama apabilah mereka dibiasakan untuk membudayakan antri dan apabilah mereka diajarkan

19 Sawiah, Guru dan bendahara, "wawancara," di Rumah beliau pada tanggal, 2 Agustus 2018.

20 Lina Rambalino, Guru, "wawancara," di ruangan beliau pada tanggal, 3 Agustus 2018

21 Nurhani, kepala sekolah, "wawancara," di ruangan beliau pada tanggal, 4 Agustus 2018. 
untuk mengembalikan barang pada tempatnya. Karena peserta didik disekolah TK AlKhairaat Uedele sangatlah susah untuk diajarkan antri oleh karena itu dalam mengajarkan budaya antri atau sikap disiplin maka seorang guru harus memiliki berbagai macam cara agar menarik perhatian anak seperti pernyataan informan berikut ini:

Peserta didik yang tidak mau diatur atau sangat susah diatur antri atau berbaris maka ibu akan panggil naik kedepan untuk jadi pemimpin barisan atau tidak memindahkan mereka kebarisan paling depan. ${ }^{22}$

Salah satu pembentukan karakter dengan disiplin/antri seperti cara ini merupakan tindakan yang baik untuk masa depan anak agar anak dapat menjadi anak bangsa yang dapat berperilaku disiplin.

\section{Aturan Yang Diterapkan Belum Dipatuhi Oleh Anak Didik}

Guru di Taman Kanak-Kanak Al-Khairaat Uedele selalu menyampaikan kepada anak-anak didik mengenai peraturan-peraturan yang harus dipatuhi, namun masih banyak anak didik yang belum melaksanakan apa yang sudah diperintahkan kepada mereka. Misalnya menyimpan kembali barang atau benda yang sudah diambil ketempat semula. Sebagaimana yang dikemukakan oleh Nurhani saat penulis temui di ruanganya:

Disekolah TKAl-Khairaat Uedele ini masih banyak yang belum mematuhi peraturan misalnya apabilah disuruh menyimpan kembali barang atau benda yang sudah mereka ambil kemudian dikembalikan ketempat semula atau membuka sepatu sebelum masuk kelas, hal ini mengajarkan mereka tentang bagaimana bertanggung jawab. ${ }^{23}$

\section{Terbatasnya Sarana dan Prasarana}

Salah satu faktor untuk menunjak keberhasilan suatu lembaga, yakni lembaga pendidikan formal adalah tersedianya sarana dan prasarana dalam pelaksanaan kegiatan pembelajaran khususnya tata cara sholat atau praktek sholat. Yang dapat membentuk karakter islami pada peserta didik, dengan terbatasnya fasilitas di Sekolah Taman KanakKanak Al-Khairaat Uedele merupakan salah satu faktor yang menghambat pembentukan karakter pada peserta didik. Terutama mengajarkan mereka tata cara sholat yang seharusnya diajarkan sejak usia dini tetapi terhambat dengan kurangnya fasilitas di Sekolah Taman Kanak-Kanak Al-Khairaat Uedele, sebagaimana yang dinyatakan oleh informan sebagai berikut:

Belum tersedianaya fasilitas yang akan digunakan, sebagai sarana dan prasarana untuk melakukan praktek, antara lain ruangan yang sangat keciluntuk dijadikan tempat sholat sehinnga tidak dapat menampung semua Anak Didik yang ada di Sekolah TK ini. ${ }^{24}$

Untuk menanggulangi kendala-kendala tersebut yang dihadapi oleh Kepala Sekolah dan Guru di Sekolah TK Al-Khairaat Uedele dalam melakukan pembentukan karakter pada peserta didik maka pihak sekolah melakukan upaya-upaya sebagai berikut:

22 Nurhani, kepala sekolah, "wawancara," di ruangan beliau pada tanggal, 4 Agustus 2018.

23 Nurhani, kepala sekolah, "wawancara," di ruangan beliau pada tanggal, 4 Agustus 2018.

24 Nurhani, kepala sekolah, "wawancara," di ruangan beliau pada tanggal, 4 Agustus 2018 
a) Pihak Sekolah berusaha semaksimal mungkin untuk melengkapi, memperbaiki, dan memenuhi segala kekurangan yang ada di Sekolah tersebut, seperti: memperbaiki dan menambah fasilitas yang ada di Sekolah tersebut.

b) Menulis tata tertib kelas yang akan selalu diingatkan kepada peserta didik agar mereka selalu mengingatnya dan dapat mematuhinmya.

c) Pada saat selesai berbaris peserta didik di tanya-tanya mengenai apa saja yang dilakukan di Rumah pada saat sepulang sekolah hingga malam hari sampai pagi sebelum kesekolah misalnya: "dipanggil satu-persatu untuk maju kedepan lalu ditanya kemarin pulang sekolah apa yang iyat bikin, terus tadi malam belajar, tadi sebelum kesekolah mandi, sikat gigi." Kemudian pada saat peserta didik sudah selesai ditanya lalu mereka sudah menjawab lalu gurunya berkata tidak bohong, maka disinilah mereka diajarkan untuk persikap jujur. ${ }^{25}$

\section{KESIMPULAN}

1. Upaya pembentukan nilai karakter yang di terapkan guru pada anak Islam Usia dini di Tk Al-Khairaat Uedele Kec. Tojo Kab. Tojo Una-Una ditemukan ada 5 tingkat pencapaian pembentukan nilai karakter anak diantaranya melalui sebagai berikut: Membiasakan anak untuk cium tangan kepada guru, Membiasakan sikap menjawab salam dan antrian kepada anak usia dini,Membiasakan dengan bernyanyi, Mengajarkan tentang tata cara shalat dan hukumannya dengan bermain.

2. Dalam membentuk nilai karakter anak Islam di TK Al-Khairaat Uedele yang dilakukan oleh guru yaitu dengan melalui cara sebagai berikut: bernyanyi, bermain,pembacaan do'a, memberi semangat dan motivasi.

3. Dalam Pembentukan nilai karakter pada anak Usia dini di TK Al-Khairaat Uedele, Kec. Tojo, Kab. Tojo Una-Una tentu banyak kendala yang dihadapi oleh guru di TK Al-Khairaat Uedele adapun kendala yang dihadapai sebagai berikut: guru belum terlalu menguasai lagu, sikap anak yang beragam, aturan yang diterapkan belum dipatuhi oleh anak didik, dan terbatasnya sarana dan prasarana.

\section{DAFTAR PUSTAKA}

Azzet, Akhmad Muhaimin. 2013. Urgensi Pendidikan Karakter Di Indonesia, Cet.2. Jogjakarta: Ar-Ruzz Media.

Suyadi. 2013. Strategi Pembelajaran Pendidikan Karakter. Bandung : PT Remaja Rosdakarya.

Syafri, Ulil Amri. 2014. Pendidikan Karakter Berbasis Al-Qur'an, Cet, ke-02. Jakarta : PT Rajawali Pers.

\footnotetext{
25 Nurhani, kepala sekolah, "wawancara," di ruangan beliau pada tanggal, 4 Agustus 2018.
} 